\title{
Model of state support for organic farming of Kazakhstan in the context of creation of international regulatory framework for the industry
}

\author{
Dilara S. Samenbetova ${ }^{1}$, and Oleg Yu. Patlasov 2.3.* \\ ${ }^{1}$ Omsk Humanitarian Academy, 4th Cheluskintsev st., 2a, 644144 Omsk, Russia \\ ${ }^{2}$ Pushchino State Institute of Natural science, 3 Prospekt nauki, Pushchino, Russia \\ ${ }^{3}$ K.G. Razumovsky Moscow State University of Technologies and Management (the First Cossack \\ University), 73, Zemlyanoy Val street, Moscow, Russia
}

\begin{abstract}
The paper evaluates the status and prospects for a wider market capacity of organic foods and items. The paper analyzes regulatory framework for organic market in Kazakhstan. The paper describes the conditions for the development of the organic market. The transformation of global food market structures has influenced the organic farming. Demand for organic products has been growing rapidly. Whereas the European Union has put in place at the time an effective system for regulating organic production, the EAEU, CIS, and SCO countries can see this production taking shape only now. It is argued that Kazakhstan is harnessing its agricultural potential only partially, including organic food production. The paper proves that the development of green farming entrepreneurship in Kazakhstan will enable agricultural organizations, aided by the measures of state support, to form a new niche in the market for organic products and expand the supply of organic products in the world market. New approaches are proposed for the first time in regard to formulating regulations, model laws, and recommendations of international unions.
\end{abstract}

\section{Introduction}

In 2013 Kazakhstan gained new opportunities in the development of the organic market following the approval of the concept for the transition of the Republic of Kazakhstan to green economy for 2013-2020 [1, p.10]. Within the shortest possible time, the Government developed standards for agricultural products.

Pursuant to the concept and based on international standards, the Government adopted the Law "On Production of Organic Goods" in 2015. This law governs organic production processes, which, in turn, will enable Kazakhstan to join the international organic market and, thus, the state will be able to regulate the import and export of domestic products. Kazakhstan possesses huge lands, which are traditionally farmed without the use of

\footnotetext{
*Corresponding author: opatlasov@mail.ru
} 
synthetic fertilizers and pesticides [5]. This aspect carries a huge privilege for the EAEU country. Production and sales of organic farm produce is an objective national competitive advantage for Kazakhstan's agro-industrial complex.

The law is in line with the rules and regulations of the international law of IFOAM and, thus, complies with international quality and control standards for organic products [21]. The adoption of this law allows Kazakhstan to participate in the world organic trade market and has positive implications for the development of farming in Kazakhstan. Along with the adoption of the main law regulating the organic foods market of the Republic of Kazakhstan, the Government has also introduced new standards and rules for organic farming.

Currently, many countries have put in place laws and standards regulating the production and labeling of organic products, with special international organizations established in order to monitor compliance. Relative to other CIS countries, Kazakhstan adopted the Law on Organic Agriculture quite recently. Well, yet the standards and rules have been adopted relatively recently. I would like to note that the executive orders for the law administration are still at the stage of development. Kazakhstan has not yet designed a national overarching plan for the development of an organic production system.

The organic market of local products should be considered from a perspective of the world organic market. If we compare the experience and indicators of other foreign countries in setting up organic production, it can be noted that Kazakhstan is only at the initial stage of the organic market development.

\section{Materials and methods}

The paper evaluates the status and prospects for a wider market capacity of organic food products. The research presents the model for enhancing the ways in which state support is offered to the organic farming market in Kazakhstan and has revealed the linkage between organic farming in Kazakhstan and environmental, social and economic indicators.

As the study has showed, Kazakhstan, like other EAEU states, faces similar challenges when it comes to organic agriculture: underdeveloped internal market for organic food products, weak financial institutions and the lack of comprehensive government support aimed at encouraging the production of organic food; lack of national statistics on the production and export of organic products, and inadequate regulatory framework for both the internal and external organic markets.

The research has applied general scientific methods for getting to know socio-economic phenomena and processes: logical and analytical methods, classification, systemic and integrated approaches, synthesis and comparative analysis. Scientific novelty of the research outcome is to develop proposals on how to improve the institutional and legal foundations of the organic market, where such proposals are about putting in place a mechanism for the state supervisory body to accredit private and public certification organizations, setting up country's own certification authority that would comply with international generally accepted standards, harmonizing national laws with international laws and introducing standards for subsidizing organic agriculture into the legal field of Kazakhstan.

The hypothesis of the study is that governmental measures to support the agricultural organic market - as a link between production and consumption - are a prerequisite for ensuring and implementing country's green entrepreneurship, improving the quality of food security, and whether it is permissible to use organic mineral fertilizers in building organic farming. However, the organization and infrastructure of the above-mentioned market are imperfect, requiring appropriate theoretical and practical applications, reliable justifications, and the formation of a new market segment. 


\section{Results and discussion}

Over the past 30 years, more than 187 countries out of 230 countries have been actively developing organic farming. Primary consumers of the organic foods market are the USA, Canada, the European Union countries - such as Austria, Germany, Great Britain, France and Japan. It should be noted that about $78 \%$ of organic products are consumed by highly developed industrial countries of Europe and the United States. According to review by FiBL \& IFOAM - Organic International (2020), 72.3 million hectares of farming land are eco-clean (including uncultivated areas) [15].

There is no official statistics on organic foods production in Kazakhstan, with no public register of organic producers available either. According to the National Accreditation Center, in 2019 Kazakhstan ranked $9^{\text {th }}$ in the exports of organic foods to the EU countries, having increased supplies to 85,675 tons, although in 2018 exports amounted to 50,250 tons. That being the case, Kazakhstan ranks $6^{\text {th }}$ in Asia in terms of the total area of organically certified land, but in the future the country may become Asia's third country after China (3,135,000 ha) and India (1,938,221 ha). The following countries have become the main exporters: Great Britain, Italy, Germany, France, Belgium, the Netherlands, Poland, Russia, Ukraine and other countries [1, p. 32]. According to the annual statistics by FiBL \& IFOAM - Organic International (2020) - FiBL survey 2021, Kazakhstan - as at year-end of 2019 - has joined top 10 countries with a high growth in the use of organic lands (Figure 1).

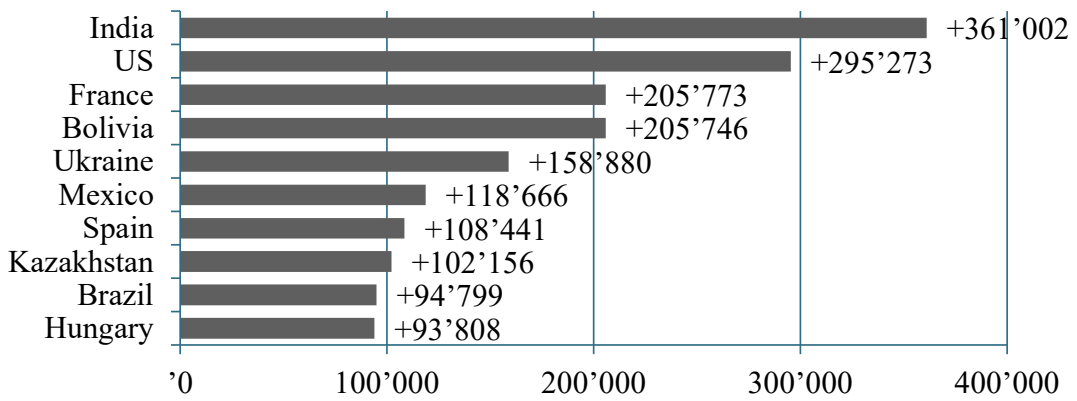

Fig. 1. Top ten countries with the highest gain in organic land in 2019 (hectares) [21].

Likewise, according to statistics at year-end 2018, Kazakhstan has used 192,134 hectares of land for organic production purposes [15]. This roughly makes $0.1 \%$ of the share of the total organic land. If we analyze this figure for 2017, we can see that the size of organic lands has decreased. In 2017, the size of organic land was 256,741 hectares, which is 64,607 hectares less than in 2018. But in 2019, area of agricultural organic land increased by almost 102,156 hectares. In the context of 10 years, Kazakhstan has certainly achieved a gain of almost $42.5 \%$. There is no official statistics nationwide on producers, but according to the data provided by the source presented above, 63 producers make organic food products in Kazakhstan, which includes 22 businesses engaged in the storage and processing of organic products, 7 businesses doing imports, and 14 in exports. According to the annual statistics by FiBL \& IFOAM - Organic International (2020) - FiBL survey 2021, at year-end 2019 Kazakhstan joined DAC countries (Development Assistance Committee) list with the largest areas of organic agricultural land in 2019 (Figure 2). 


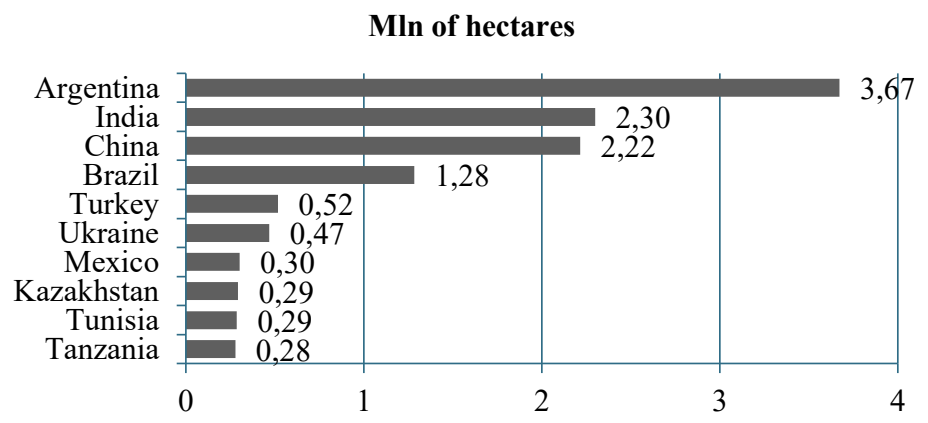

Fig. 2. Top 10 countries from DAC list with the largest areas of organic agricultural land in 2019 [21].

For farmers of Kazakhstan, organic products are still an unknown variable in the large realm of agriculture. Apart from more obvious advantages of natural production, organic production is more complicated due to an extensive number of requirements for the growing process. Currently Kazakhstan has more than 63 such producers, and the real organic pioneers are the farmers of the Kostanay Region. Over 15 types of farm produce are exported from Kazakhstan to Europe - peas, Sudan grass, duck wheat, lentils, flax, sainfoin, soybeans, chickpea, oats, spring wheat, sunflower, millet, false flax, wheatgrass and spring barley. Globally known flax - which is actively purchased by Germany, Switzerland and Italy - is also exported from Kazakhstan. Organic lentils are also very popular abroad, purchased in large volumes by Italy and Turkey. Exports are also made up of cereals, but not in such large volumes. There is a farm in the Almaty Region which deserves special presentation - the farm is the only one in Kazakhstan certified for the wild collection of medicinal herbs, the main buyer of which is located in Germany.

In recent years, Kazakhstan has become one of the international leaders in the export of flax. Thus, in 2020, local producers sold almost 15 thousand tons of certified organic flax worth about 9 million euros. In 2019, they sold about 7 thousand tons for about 4 million euros. In general, Kazakhstan is the $10^{\text {th }}$ top player in the European organic market of oilseeds. Also, Kazakhstan sold about 6 thousand tons of organic wheat worth about 1.5 million euros. Well, here we face a paradoxical situation in which although more organic grain is produced in Kazakhstan, it is exported less than flax. One reason is that in recent years Europe has seen the emergence of more local farmers growing organic wheat. Russia is also a strategic export partner. In the Russian Federation, the domestic organic market in 2018 was worth $\$ 183$ million euros. Russia's own production supplies only $20 \%$ of the demand for organic foods, with $80 \%$ coming from imports. Therefore, there are no artificial barriers in Russia that would prevent organic products from Kazakhstan from being on the shelves. In addition, it is convenient for our farmers to be in a single market within the EAEU, as well as to enjoy simple logistics. Russia buys organic foods from Kazakhstan, but so far there have been fewer orders from Russia than from Europe.

One of the main aspects for the development of the organic foods market in Kazakhstan is a matter of organic certification. In order to secure international certification, farmers and processing companies request certification from certification organizations. They are certified depending on the target market: under the terms of Council Regulation (EC) $834 / 07$ for exports of products to the European market or under the terms of the NOP for exports of products to the North American market [9, p. 73]. The Certificate enables producers to label their products as organic product abroad. The following international companies currently operate as certifiers in Kazakhstan: Austria Bio Garantie GmbH; 
CERES Certification of Environmental Standards GmbH; Ecocert SA; Institute for Marketecology (IMO); Istituto Certificazione Etica e Ambientale; LACON GmbH; SGS Austria Controll-Co. GmbH; Ecoglobe; Organic standard.

Kazakhstan has large enough areas for organic farming, which make up roughly 300 thousand hectares. But in order to certify land as organic, large financial investments are needed, which makes it impractical for farmers to request certification for less than 1000 hectares of arable land. Well, here the issue of reducing certification costs comes into play. For example, decreasing the price of certification by 2.5 times will respectively reduce the threshold for organic farming to 400 hectares. This measure will enable even small farmers to start organic farming. The south of the country is able to grow vegetables and fruits according to organic standards. Organic farming requires at least 100 hectares of land. But the south doesn't have such areas, as all the land plots are fragmented [12]. So the South does not do organics. Only in the Almaty Region there is a farm that exports organic soybeans, so reducing the minimum certifiable area to 40 hectares will change the situation and make the south the driver of organic production [11].

Quite high export figures have no impact on the internal market whatsoever. Farmers are not willing to develop this segment, with many not even aware of how to establish a supply chain to retail stores. Thus, producers and buyers have to be reached out in order to build awareness, which needs to be supported at government level. At the moment, the Union of Organic Producers of Kazakhstan is actively engaging with farmers in Kazakhstan in order to raise their awareness, offering pre-audit consultations. The opportunities and risks of organic farming are explained to producers, letting the farmer further decide whether to send products for export or sell the finished product in the domestic market. Therefore, the Union of Organic Producers needs to keep raising farmers' awareness across each aspect. Focus should be placed not only on the production, but also on processing, drying, primary treatment, land allotment, storage, and networking for sales systems. So, an important step in this respect will be to set up an export-oriented trade and processing cooperative (or a system of cooperatives) that would unite several regional producers. This will make it possible to make organic products and move away from the raw feeds model. In accordance with the standards, an organic producer must store and transport in a proper manner, i.e. there has to be a certified transport mode. This makes it relevant to consider creating in the future a northern regional hub in Kazakhstan to promote local organic products. It is necessary to focus on this issue. There is also a need to consider whether it is possible to establish logistics centers in Nur-Sultan and Almaty with appropriate storage facilities for the export of eco-friendly products to the EAEU countries and farther abroad.

Another strategic area of green entrepreneurship in Kazakhstan is the promotion of the umbrella brands of Qazaq Organic and Halal Qazaqstan. Organic items are already produced under the Qazaq Organic Food logo, and they are also exported to Europe. Thus, the goal behind establishing umbrella brands is to create a trendy character and branding that will unite all isolated brands according to certain identity principles. In the future, Qazaq Organic Food plans for additional export opportunities through recognition both in the domestic and foreign markets among producers and consumers. Therefore, additional coverage is needed in the local market for the Qazaq Organic Food brand. Country branding is becoming more and more popular, with more and more countries around the world committing considerable resources to the development of their national brands $[10$, p.100]. Of course, the issue of a single umbrella identifier applies to all umbrella brands. Consumers of organic foods are already familiar with the following brands: Zharkol-007 LLP, Bio Tau Zher LLP, Honey KZ SEC, and Karzhau Farm Business. For them, these products associate with domestic organic production. The Federation of Organic Agriculture Movements - KAZFOAM, the Kazakh Research Institute of the Agricultural Economics and Rural Development, and the Union of Organic Producers of Kazakhstan are 
the main groups that support and implement organic agriculture in Kazakhstan. Having done the analysis of the strategic areas for the development of green entrepreneurship in Kazakhstan, it can be argued that the state does not provide direct support. There are indirect measures of regulation in the form of a legislative framework and institutions, but they also need to be improved.

As part of the study of the domestic retail market for organic products in Kazakhstan, the authors conducted a survey of Internet users with a poll called "Analysis of the Organic Market for Products of Kazakhstan". About 500 respondents over the age of 20 were interviewed, involving the working population from governmental structures and businesses. Based on a social study, the authors made conclusions about the attitude of Internet users to the organic food market. There is no solid awareness yet. Residents of Kazakhstan learn about most of the benefits of organic products from the Internet, with the consumer not really aware of the difference between the labels such as "organic", "organic products", "BIO", "GMO-free", "eco-products", "natural product", not knowing about strict requirements for the production and labeling of organic products. For some, all organic products are just a sales pitch. This gives rise to a relevance of issue of certification and labeling. After all, only the "organic" label and a conformity mark next to it make any consumer $100 \%$ confident about the natural origin of raw materials and high quality without the use of any chemicals, preservatives, GMOs, and so on. Moreover, a large share of consumers in Kazakhstan is unaware of the labeling of organic products using a special conformity mark. In most cases, a consumer will read the information on the package that this food product complies with the established GOST. In Kazakhstan, there is no unified certification system in accordance with an international certificate, while getting a certificate from international bodies is costly. Therefore, it is utterly unrealistic for a producer to enter the international market without state support.

\section{Conclusions}

Based on the above conclusions and findings, the authors have made the following recommendations. First, domestic organic producers in Kazakhstan should raise public awareness of the benefits of environmentally friendly products. Consumers should be able to distinguish between pseudo-labels and special marks (approved at the legislative level). Secondly, there is no register of organic producers in Kazakhstan and, in fact, the state does not provide adequate support to them. With that being said, according to the survey, many respondents trust domestic producers for the most part due to the proven benefits of natural products. The "Qazaq Organic Food" State Program is gathering pace, so the communications and outreach policy to promote organic products must be arranged in such a way as to allow the local public to become familiar with domestic producers and trust them just as they would trust foreign producers. Thirdly, when assessing the capacity of the organic foods market, the authors have revealed that primary consumers are upper income families with children. Hence, the awareness-raising policy must emphasize the benefits of consuming organic products on a daily basis. Family shopping is not a spontaneous act, so the sales points need to be conveniently located and be on everyone's lips. Availability of online stores and delivery channels increases the probability of purchase. In their marketing strategies, organic producers should place the right emphasis, accommodating the preferences of married couples with children. Thus, we believe that these results of the sociological survey and the measures will increase the share of organic food, and can be used for further research.

Today, the issue of improving a number of measures of state support for organic production has become relevant. If Kazakhstan wants to develop organic farming and agriculture, then it is essential that a whole range of measures be delivered. Regulation and 
establishment of new national standards is considered to be the most important task of the country's government in the near future. In order to increase the share of organic exports, it is necessary to harmonize national standards with those of the exporting countries. One of the drivers of this process will be the accreditation of Kazakhstan's certification body in the exporting country.

Currently the local situation in Kazakhstan with the certification of organic products is that it takes at least 3 years to get certified in the EU. A total of 19 companies have been accredited by the EU to grant certification to producers of organic items in Kazakhstan. The nearest laboratory that meets international standards is located in Chisinau and Kiev, with $90 \%$ of organic exports from Kazakhstan certified by Ukrainian partners. Therefore, establishing our own certification authority is a key issue for the development of organic agriculture in Kazakhstan. It is necessary to set up laboratories that will test products for hazardous substances. The estimated cost of this would be approximately 10 million euros. So, at the moment, a farmer incurs enormous costs of international certification procedure: a lot of money is spent to invite a specialist, send lab samples for verification, as well as to implement transportation and storage. With a farmer spending at the moment about 10 and more thousand euros to obtain a certificate of conformity, this will cost producers 3-4 thousand euros once there is a local certification authority. So, the price of organic products in the market will be only $20 \%$ more expensive than traditional items. Thus, once there is an in-house certification authority and laboratory in the country, this will reduce the unit cost of organic products, which will have a beneficial effect on the development of the domestic market. With an in-house lab, Kazakhstan will be able to offer certification to the nearest countries, which also lack their own organics certification resources: Kyrgyzstan, Uzbekistan, Tajikistan, Russia (border areas). Due to its territorial advantage, Kazakhstan will be able to become a strategic partner for these countries. Certification of organic products will make it possible to finally deal with labeling and pseudo-labeling issue, when the "bio" and "eco" marks will be considered only a sales pitch, while the "organic" label will inspire confidence. Consequently, there will be an opportunity to promote the national brand of environmentally friendly products - Qazaq Organic Food - in the organic market of the Republic of Kazakhstan.

The next measure in the development of organic products is to improve the Law of the Republic of Kazakhstan "On the Production of Organic Goods" adopted in 2015. Along with this, it is necessary to update the regulations and standards governing all players in the organic market: farmers, traders, and certification authorities.

We believe it is practical and important to enact the following legislative innovations. We would like to emphasize a few points in this respect

1. The Law of the Republic of Kazakhstan "On the Production of Organic Goods" does not contain a definition on self-certification, i.e. most of the small organic producers are not actually certified by a third party, but are self-certified under a system developed by IFOAM and called the PGS - Participatory Guarantee System (or Community Guarantee System) [12]. But according to the law, such products cannot be called organic. Some countries also do not deal with self-certification; however, for small producers - that start their organic production - this measure will help to join the domestic market, and then export.

2.In Kazakhstan, there is no mandatory official statistics on organic products, no register of organic suppliers as well as no database of organic seeds. In the EU, this sort of database operates at the legislative level, but the EU exporters do not require it from other countries. But maybe in the future, once the harmonization of standards takes place, lack of such a database on Kazakhstan will affect the opportunities to sell locally made products to the European markets. 
3. The Law of the Republic of Kazakhstan "On the Production of Organic Goods" does not have an article on mandatory certification of importers in Kazakhstan. This measure will help the Ministry of Agriculture to analyze the market of organic imports.

4. Introduction of the requirement that foreign certification bodies operating in the country shall be mandatorily registered in Kazakhstan. Since Kazakhstan is now on the EU gray lists for organic products, this measure will allow government agencies to rehabilitate the country's position on the list of faithful suppliers. As already noted, Kazakhstan is in the group of risk countries, which makes certification 2.5 times more expensive than for countries that are considered well-to-do by the EU.

5.Harmonization of domestic and international certification. At the moment, farmers with certificates from foreign countries of the EU, the US, Canada, and China cannot sell their products in the domestic market as organic, and they need to obtain local certification. This is why farmers - who have already incurred financial costs due to receiving international certification - no longer want to request domestic certification, which has a bad effect on the development of the domestic market.

6. The Law of the Republic of Kazakhstan "On the Production of Organic Goods" does not define the issue of subsidies. That is, the Law does not describe either interest rates for the purchase of fertilizers for organic agricultural production, or any preferential loans and grants for beginning entrepreneurs. However, we would like to note that Order of the Minister of Agriculture of the Republic of Kazakhstan No. 107 dated March 30, 2020 approved the rules for subsidizing gains in yields and quality of crops. The rules clearly state that there are several subsidizing areas in accordance with the Law, including subsidies for mineral fertilizers (except for organic fertilizers). This factor does not contribute to organic farming in Kazakhstan. So-called per hectare support is also needed, especially during conversion period, when a business is moving from classic to organic production, and this subsidy should be 3-5 times higher than classic support.

At the moment, the law is more of a framework rather than a delivery plan, with a lot of work needed in the preparation of by-laws aimed at putting in place a delivery mechanism. The National Accreditation Center deals with internal certification. NAC specialists noted that there are no applications for local certification, which shows that the domestic market is developing very slowly in Kazakhstan. Thus, it is necessary to avoid double certification, which will help increase the share of the domestic organic market by reducing production costs. The process of harmonization of European and domestic standards requires strong focus.

Relating to the development of organic farming in the CIS countries, the main issue that needs to be addressed is the synchronization of the countries' laws and shaping the general law on organic agriculture, which would be harmonized with all national laws. There are no systematized national strategies in the EAEU states, with the regulatory measures often posing additional barriers and not encouraging the production of organic foods and items. Thus, a prospective dimension for integration between EAEU states in developing an organic market is the following: working on national aware-raising and consultative systems, harmonization of systems of public registration of bio-drugs, crop nutrients and protection, international cooperation, introduction of systems for keeping track of organic products. The first step in this direction has already been made - the roadmap approved on August 23, 2021. Entering into an international treaty aimed at ensuring the free movement of organic farm produce across the EAEU will simplify certification procedures, and will contribute to fair competition, and more importantly, cooperation. The next step should be to create a common legislative model for all countries.

It is important for domestic agricultural organic producers to make it into the "List of Competitive Products" of the CIS countries, which currently includes 330 producers of Kazakhstan in the "Agricultural and Food Products" section. 
It is also necessary to consider the international cooperation of the SCO. Measures to enhance regulatory and legal framework as part of the updated Program for Multilateral Trade and Economic Development of the SCO member states, as well as practical interchange and implementing innovative solutions in the agricultural sector particularly concerning organic agriculture will make it possible to establish a single legal environment for international cooperation in organic farming. Particular emphasis shall be placed on the infrastructure for marketing organic products, including to international markets, specifically relating to establishing a national lab in the Republic of Kazakhstan certified in the EU. The state has not yet allocated roles between state authorities, ministries and market players such as producers, consumers, suppliers, and traders. There is no system for collecting information on the number of producers, certified land, market size and other components, which would serve as a basis for further development forecasts. Improving the legislative framework, legal and institutional structures in the future will be able to produce a synergizing effect in the development of both the internal and external markets for organic products.

\section{References}

1. State Program for the Development of the Agro-Industrial Complex of the Republic of Kazakhstan for 2017-2021. http://extwprlegs1.fao.org.

2. Law on Organic Products and Amendments to Certain Legislative Acts of the Russian Federation. Adopted by State Duma (2018) https://rosorganic.ru

3. Law of the Republic of Kazakhstan No. 423-V dated NOV27 (2015) "On Production of Organic Goods", http://adilet.zan.kz.

4. Draft Concept of Development of Measures to Support Domestic Producers and Processors of Agricultural Goods based on Domestic Food Aid Arrangements within WTO Green Box, http://www.mcx.ru.

5. On Organic Products and Amendments to Certain Legislative Acts of the Russian Federation. Federal Law (2018) No. 280-FZ.

6. Order of the Ministry of Health of Russia dated January 15, (2020) N. 8 approved the Strategy for Promotion of Public Healthy Lifestyle, Prevention and Control of NonCommunicable Diseases until 2025.

7. Sanitary Regulations and Standards 2.3.2.2354-08 "Additions and amendments No. 8 to Sanitary and Epidemiological Rules of SRG 2.3.2.1078-01 "Hygienic Requirements for Food Safety and Nutritional Value of Foods" (registered with Russia's MoJ on March 22, (2002), reference No. 3326)

8. Ye. Varavin, M. Kozlova. Economy of the Region, 14(4), 1282 (2018)

9. V. Grigoruk, Y. Klimov, Development of Organic Farming in the World and Kazakhstan, 153 (2016) http://www.fao.org.

10. I. Degtyarev, G. Tokareva, O. Shalina, Bulletin of Perm National Research Polytechnic University. Social and Economic Sciences, 3, 180 (2016)

11. N. Krasovskaya, A. Deyev, S. Chernomorenko, Science Journal, 6 (2018) https://esj.today.

12. V. Kruchinina, VGUIT Bulletin (Voronezh State University of Engineering Technologies), 79(2), 296 (2017)

13. O. Mironenko. Russia's Organic Market. Results of 2017. Prospects for 2018, Mironenko Analitika (2017-2018) 
14. D. Samenbetova, O. Patlasov, Human Science: Humanitarian Research, 2(36) 210 (2019)

15. FiBL\& IFOAM -The World of Organic Agriculture - Statistics and Emerging Trends (2019) https://ciaorganico.net

16. L.M. Jespersen, D.L. Baggesen, E. Fog, Organic Agriculture, 243 (2017)

17. L. Marsh, E. Zoumenou, C. Cotton, F. Hashem, Agriculture, 125 (2017)

18. E. Roos, A. Mie, M. Wivstad, Agronomy for Sustainable Development, 14 (2018)

19. F.A. Shafi, D. Rennie, Procedia Social and Behavioral Sciences, 49, 360 (2012) https://www.sciencedirect.com

20. S. Mann, Socioeconomics of Agriculture, 41 (2018) https://www.researchgate.net

21. The Food and Agriculture Organization (FAO), http://www.fao.org.

22. The World of Organic Agriculture - Statistics and Emerging Trends (2019), https://ciaorganico.net 